\title{
Protective action of deferiprone and deferoxamine in erythrocytes isolated from patients with $\boldsymbol{B}$-thalassemias
}

\author{
Ação protetora de deferiprona e desferoxamina nos eritrócitos isolados de pacientes com \\ B-talassemias
}

\author{
Alisson F. Santos ${ }^{I}$ \\ Giorgio Baldanzi ${ }^{2}$ \\ Maria Suely S. Leonart ${ }^{3}$ \\ Aguinaldo J. Nascimento ${ }^{4}$
}

\begin{abstract}
One of the most deleterious consequences of iron overload in thalassemia is the presence of non-transferrin bound iron (NTBI), a free radical that acts as a catalyst for free oxygen radicals, in particular for hydroxyl free radicals $(\mathrm{OH}$.). These radicals oxidize both membrane lipids and proteins causing irreversible damage to biologically important molecules and cellular structures. Treatment with iron chelators has been important to improve survival of these individuals. The aim of this work was the study on the effects of deferoxamine (DFO) and deferiprone (DFP) on erythrocytes under the pro-oxidative action of TBHP isolated from normal individuals and patients with $\beta$-thalassemia. The in vitro action of deferoxamine and deferiprone on the oxidative metabolism of erythrocytes from $\beta$-thalassemic patients treated at the Centro de Hematologia e Hemoterapia do Paraná (HEMEPAR), Brazil, under the pro-oxidative action of TBHP was studied. Methemoglobin concentrations, reduced glutathione (GSH), hemolysis indexes and the enzyme activities of G6-PD and GR were determined. The oxidation indexes were higher in erythrocytes of $\beta$-thalassemic individuals than those from normal individuals. Treatment of the normal and $\beta$-thalassemic erythrocytes with DFO and/or DFP protected against the formation of GSH promoted by TBHP. Rev. Bras. Hematol. Hemoter.
\end{abstract}

Key words: Iron chelators; deferoxamine; deferiprone; erythrocytes.

\section{Introduction}

Iron is essential for all organisms, where it participates in some metabolic processes, such as the transport of oxygen by hemoglobin in the erythrocytes, synthesis of DNA and electron transport. ${ }^{1}$ However, in higher amounts, it is harmful to the health for the generation of free radicals, which can initiate lipid peroxidations in the membrane, as well as aggression to proteins of tissues and membranes, to enzymes, carbohydrates and DNA. ${ }^{2}$

Patients with $\beta$-thalassemia major have body iron overload, originated from frequent transfusions and gastrointestinal iron hyperabsorption. Each milliliter of transfused red cells contains approximately $1 \mathrm{mg}$ of iron. ${ }^{1}$ There is also an accumulation of additional iron, due to the deficiency of production of normal hemoglobin protein chains. ${ }^{3}$ The excess of iron is deposited in the endocrine, hepatic and/or cardiac system causing functional damage to the organs. ${ }^{4}$

According to Cohen et al. ${ }^{5}$ iron chelator used therapeutically has the objective of lowering the amount of this metal to safer levels, avoiding complications in the

${ }^{l}$ Farmacêutico-Bioquímico. Centro de Hematologia e Hemoterapia do Paraná - Hemepar - Curitiba-PR

${ }_{3}^{2}$ Médico Hematologista e Hemoterapeuta. Centro de Hematologia e Hemoterapia do Paraná - Hemepar - Curitiba-PR.

${ }^{3}$ Professora Titular da Universidade Federal do Paraná - Curitiba-PR.

${ }^{4}$ Professor senior da Universidade Federal do Paraná - Curitiba-PR.

Programa de Pós-Graduação em Ciências Farmacêuticas, Universidade Federal do Paraná - Curitiba-PR.

Correspondência: Alisson Fernandes dos Santos

Centro de Hematologia e Hemoterapia do Paraná (Hemepar)

R. João Prosdócimo, 145

80060-220 - Curitiba, PR - Brazil

E-mail:alibioq@hotmail.com 
organism. The ideal properties of the chelators should be specificity and affinity by $\mathrm{Fe}^{+3}$; efficiency of the chelating action; easy penetration in organs and tissues; no redistribution of the iron; relatively low toxicity; low cost and viability for oral administration. Deferoxamine (DFO) and deferiprone (DFP) has been used in the treatment of $\beta$-thalassemic patients. DFP has a lower molecular size than DFO, and penetrates more easily in the cells. ${ }^{6}$

The pro-oxidative action of tert-butyl hydroperoxide (TBHP) has been used to analyze the oxidative stress in isolated erythrocytes. ${ }^{7}$ It can cause metabolic alterations such as unbalance on the homeostasis of intracellular calcium; oxidation of the reduced glutathione, and of proteins tiol groups; damages on DNA molecules; lipid peroxidation; lowering of the intracellular mobility of the membrane proteins. $^{8}$

The understanding of the oxidative stress mechanisms helps to explain many of the processes of cellular lesion and death, especially those related to the hemolytic diseases. The sickle cell anemia, thalassemias and glucose 6-phosphate dehydrogenase (G6-PD) deficiency are among the more frequent genetic anomalies accompanied by oxidative stress. The oxidative action induced by TBHP was observed in erythrocytes from patients with sickle cell anemia by the increase on the content of Heinz bodies, methemoglobin, hemolysis, GSH depletion and lowering activities of the enzymes G6-PD and glutathione reductase (GR). ${ }^{7}$

The aim of this work was the study on the effect of DFO and DFP in isolated erythrocytes from normal individuals and patients with $\beta$-thalassemias, under the prooxidative action of TBHP.

\section{Materials and methods}

\section{Erythrocytes suspensions}

Venous blood was collected in $\mathrm{CPDA}_{2}$ after informed consent, according the Ethical Committee for Research Involving Humans, Setor de Saúde of the Universidade Federal do Paraná. The samples were collected and processed in agreement with the Resolution no. 154 of the Collegiate Directory of the Sanitary Vigilance National Agency (Anvisa) of the Brazil Ministry of Health. It was collected 50 to $100 \mathrm{~mL}$ from 6 normal individuals; $10 \mathrm{~mL}$ from 5 patients with $\beta$ thalassemia minor, and from 10 patients with $\beta$-thalassemia major assisted at Centro de Hematologia e Hemoterapia do Paraná (Hemepar), Brazil. From the latter, 3 were regularly treated with DFO, and 7 treated with DFO and DFP. The blood samples were collected before the routine transfusion of the 30-days.

Blood samples with normal and $\beta$-thalassemic erythrocytes were centrifuged at $1200 \mathrm{x}$ g for $10 \mathrm{~min}$ at $4^{\circ} \mathrm{C}$ (Hermle centrifuge) and the plasma and the buffy-coat was taken by aspiration. The erythrocytes were then washed three times with $154 \mathrm{mM} \mathrm{NaCl}$ in $27 \mathrm{mM}$ phosphate buffer, $\mathrm{pH}$ 7.4, at $1200 \mathrm{x}$ g for $10 \mathrm{~min}$, and resuspended in the same buffer to a $40 \%$ cell packed volume. ${ }^{11}$ Samples of $\beta$-thalassemia major erythrocytes were not washed. Aliquots of $1 \mathrm{~mL}$, were centrifuged at $1200 \mathrm{xg}$ for $5 \mathrm{~min}$, and the supernatants were substituted by the same volume of the reagent solutions.

Samples of $\beta$-thalassemia major erythrocytes were not washed in order to keep the integrity of DFO and DFP as originally taken from the blood of medicated patients

\section{Erythrocytes incubation with deferoxamine,} deferiprone, and tert-butylhydroperoxide (TBHP)

Aliquots of $1 \mathrm{~mL}$ of erythrocyte suspensions were incubated with 1-4 mM DFO and/or 3-12 mM DFP in $154 \mathrm{mM}$ $\mathrm{NaCl}$ under homogenization, during 60 min (Phoenix HS 22). For the studies on the pro-oxidative effect of TBHP, the erythrocytes suspensions $(1 \mathrm{~mL})$ were then incubated with 3 $5 \mathrm{mM} \mathrm{TBHP}$, and homogenized during $30 \mathrm{~min}$ (Phoenix HS 22).

Stock solution of TBHP (Sigma) as $50 \mathrm{mM}$ was prepared in $67 \mathrm{mM}$ phosphate buffer, $\mathrm{pH}$ 7.6, with glucose $200 \mathrm{mg} / \mathrm{dL}$.

\section{Determination of Heinz bodies}

Heinz bodies were counted according to Beutler et al. ${ }^{9}$ modified by Claro et al. ${ }^{10}$ It was added $25 \mu \mathrm{L}$ of the treated erythrocytes to $0.5 \mathrm{~mL}$ of $67 \mathrm{mM}$ phosphate buffer, $\mathrm{pH} 7.4$ with $200 \mathrm{mg} / \mathrm{dl}$ glucose. The mixture was homogenized with the aid of an automatic pipette, and then an aliquot of $25 \mu \mathrm{L}$ was added to $50 \mu \mathrm{L}$ of methyl violet $(2 \mathrm{mg} / \mathrm{dL}$ in $0.73 \mathrm{mg} / \mathrm{dL}$ $\mathrm{NaCl}$ ), on a microscopy slide, under a coverslip. After $5 \mathrm{~min}$, erythrocytes with Heinz bodies were counted using light microscopy (1000 cells per slide). The results are expressed as the percentage of erythrocytes showing more than one violet inclusion, 1-3 $\mu \mathrm{m}$ wide, near the plasma membrane. ${ }^{11}$

\section{Determination of methemoglobin (MetHb)}

$\mathrm{MetHb}$ concentration was determined according to Evelyn and Malloy, ${ }^{12}$ modified by Beutler et al.${ }^{13}$ It was added $100 \mu \mathrm{L}$ of erythrocytes suspension in $10 \mathrm{~mL}$ of $16 \mathrm{mM}$ phosphate buffer, $\mathrm{pH}$ 6.6, and the absorbance was measured at $630 \mathrm{~nm}$ against water blank, after 5 min (Shimadzu spectrophotometer). Then, $50 \mu \mathrm{L}$ of neutralized cyanide (acetic acid $12 \mathrm{~g} / \mathrm{dL}$ and sodium cyanide $10 \mathrm{~g} / \mathrm{dL}$ ) was added to the cuvette and mixed, and a second reading at $630 \mathrm{~nm}$ was made after $5 \mathrm{~min}$. This lysate was then diluted in $66 \mathrm{mM}$ phosphate buffer, $\mathrm{pH} 6.6$ and added of $50 \mu \mathrm{L}$ potassium ferricyanide $(20 \%)$ and $50 \mu \mathrm{L}$ sodium cyanide $(10 \%)$. The absorbance was measured at $540 \mathrm{~nm}$ against the reactant blank, to measure the total amount of hemoglobin in the sample. The methemoglobin concentration was expressed as percentage of total hemoglobin.

\section{Determination of reduced glutathione (GSH)}

GSH concentration was analyzed by the method for determination of blood glutathione ${ }^{14}$ evaluating the reduction of 5,5'-dithiobis (2-nitro benzoic acid) (DTNB) by sulfhydryl 
compounds at $412 \mathrm{~nm}$ (Shimadzu spectrophotometer), and expressed in $\mu$ mole $\mathrm{GSH} / \mathrm{g}$ of hemoglobin.

\section{Hemolysis}

Hemolysis percentage was analyzed by the cyanomethemoglobin method for low hemoglobin concentrations according to Pelissari et al. ${ }^{15}$ To the hemoglobin-containing supernatant the Drabkins reagent ${ }^{16}$ was added, with dilution from 1:3 to $1: 110$, according to the visual hemolysis degree, from uncolored to brilliant red. This reaction converts hemoglobin to cyanomethemoglobin, and the concentration can be monitored at $540 \mathrm{~nm}$ wavelength (Shimadzu spectrophotometer).

\section{Freezing-thawing hemolysates}

It was added $0.1 \mathrm{~mL}$ of the erythrocyte suspensions to $1.9 \mathrm{~mL}$ of EDTA-ß-mercaptoethanol, ${ }^{17}$ and homogenized, followed by two cycle of freezing-thaw procedure: at $-20^{\circ} \mathrm{C}$ and at room temperature for $5 \mathrm{~min}$ each. The hemolysates were kept at $4{ }^{\circ} \mathrm{C}$.

\section{Activity of glucose 6-phosphate dehydrogenase (G6-PD)}

The G6-PD activity was monitored according to Beutler. ${ }^{17}$ It was added $20 \mu \mathrm{L}$ of the hemolysate $(1: 20)$ to $0.98 \mathrm{~mL}$ of reaction medium (1 M Tris-HCl, $\mathrm{pH} 8.0 ; 5$ mM EDTA, $0.1 \mathrm{M} \mathrm{MgCl}_{2} ; 2 \mathrm{mM}$ NADP). It was incubated for $10 \mathrm{~min}$ at $37^{\circ} \mathrm{C}$ and then added $100 \mu \mathrm{L}$ of $6 \mathrm{mM}$ glucose 6-phosphate. The reaction was monitored at $340 \mathrm{~nm}$ (Shimadzu UV 1601) and the enzymatic activity was expressed in $\mathrm{IU} / \mathrm{g} \mathrm{Hb}$. The molar absorptive coefficient of NADPH is $6.22 \mathrm{~L} /($ mole $\mathrm{x}$ $\mathrm{cm})$. One unit is equal to $1 \mu$ mole of NADPH formed per min.

\section{Activity of glutathione reductase (GR)}

The GR activity was monitored according to Beutler. ${ }^{17}$ It was added $10 \mu \mathrm{L}$ of the hemolysed (1:20) to $0.84 \mathrm{~mL}$ of reaction medium (1 M Tris- $\mathrm{HCl}, 5 \mathrm{mM}$ EDTA, $\mathrm{pH}$ 8.0, incubated for $10 \mathrm{~min}$ at $37^{\circ} \mathrm{C}$, and added $100 \mu \mathrm{L}$ of $0.033 \mathrm{M}$, GSSG). It was incubated for more $10 \mathrm{~min}$ at $37^{\circ} \mathrm{C}$. The reaction was started by addition of $50 \mu \mathrm{L}$ of $2 \mathrm{mM} \mathrm{NADPH}$, and monitored at $340 \mathrm{~nm}$ (Shimadzu UV 1601). The enzymatic activity was expressed in $\mathrm{IU} / \mathrm{g} \mathrm{Hb}$. One unit is equal to 1 $\mu$ mole of NADP formed per min.

\section{Statistical analysis}

The statistical significance of the experimental data was analyzed using the ANOVA and Tukey tests. A p value $<0.05$ was considered to be significant.

\section{Results and discussion}

Table I illustrates some biochemical measurements on erythrocytes from normal individuals and from patients with $\beta$-thalassemia minor and major.

Table 1. Pro-oxidizer action of TBHP and antioxidant effect of deferoxamine and deferiprone in erythrocytes of normal individuals and of patients with $\beta$-thalassemia minor and $\beta$-thalassemia major

\begin{tabular}{|c|c|c|c|c|c|c|c|c|}
\hline \multicolumn{2}{|c|}{ Erythrocytes } & Assays & $\begin{array}{l}\text { MetHb* }^{*} \\
(\%)\end{array}$ & $\begin{array}{c}\mathrm{GSH}^{*} \\
(\mathrm{Mmole} / \mathrm{g} \mathrm{Hb})\end{array}$ & $\begin{array}{l}\text { Hemolysis* } \\
(\%)\end{array}$ & $\begin{array}{c}\text { Heinz } \\
\text { bodies* }(\%)\end{array}$ & $\begin{array}{l}\text { G6-PD** } \\
(\mathrm{IU} / \mathrm{g} \mathrm{Hb})\end{array}$ & $\begin{array}{c}\mathrm{GR}^{* *} \\
(\mathrm{IU} / \mathrm{g} \mathrm{Hb})\end{array}$ \\
\hline \multirow{5}{*}{\multicolumn{2}{|c|}{$\begin{array}{c}\text { Normal§ } \\
\mathrm{N}=6\end{array}$}} & Control & 0 & 7.5 & 0.21 & 0 & 12.27 & 7.79 \\
\hline & & TBHP & 20 & 0.15 & 0.65 & 9 & 10.27 & 7.55 \\
\hline & & DFO & 3.2 & 3.1 & 0.79 & 0 & 7.71 & 7.94 \\
\hline & & DFP & 32.8 & 3.5 & 0.82 & 6.8 & 7.97 & 8.12 \\
\hline & & DFO + DFP & 21.6 & 4.62 & 0.98 & - & - & - \\
\hline \multirow{5}{*}{\multicolumn{2}{|c|}{$\begin{array}{c}\beta \text {-Thalassemia minor§ } \\
N=5\end{array}$}} & Control & 0 & 6.79 & 0.26 & 5 & 22.36 & 9.16 \\
\hline & & TBHP & 26.5 & 0.5 & 2.74 & 34 & 7.74 & 8.91 \\
\hline & & DFO & 19.4 & 1.34 & - & - & - & - \\
\hline & & DFP & 25.9 & 2.97 & - & - & - & - \\
\hline & & DFO + DFP & 31.2 & 3.74 & - & - & - & - \\
\hline \multirow{4}{*}{$\begin{array}{l}\beta \text {-Thalassemia major } \S \\
\mathrm{N}=10\end{array}$} & $\mathrm{~A} 1$ & Control & 0 & 8.17 & 0.57 & 12 & 9.76 & 9.92 \\
\hline & $N=3$ & TBHP & 26.4 & 2.85 & 6.49 & 43 & 3.33 & 9.73 \\
\hline & $\mathrm{A} 2$ & Control & 0 & 8.41 & 0.52 & 19 & 10.22 & 9.44 \\
\hline & $N=7$ & TBHP & 26.5 & 3.51 & 5.6 & 51 & 2.71 & 9.47 \\
\hline
\end{tabular}

Erythrocytes treated with *3 mM TBHP, and ** $5 \mathrm{mM}$ TBHP

Control - untreated erythrocytes; TBHP -TBHP treated erythrocytes.

$\S$ - Erythrocytes from normal individuals and $\beta$-thalassemic minor patients incubated with DFO and/or DFP prior to TBHP treatment. $\S \S$ - Erythrocytes from $\beta$-thalassemic major patients under treatment with: A1 - DFO and A2 - DFO + DFP. - not determined. 
It can be observed that under TBHP action there are methemoglobin formation; reduction of the GSH concentration; increase of formation of Heinz bodies and hemolysis percentage.

In erythrocytes from normal individuals the DFO treatment showed a protective effect, where only $3.2 \%$ of methemoglobin was observed against $20 \%$ of methemoglobin observed with TBHP alone.

$\beta$-thalassemic minor erythrocytes were more vulnerable to the pro-oxidative action of TBHP, presenting more than $25 \%$ methemoglobin. Samples treated with iron chelators and then submitted to the oxidative action of TBHP, showed methemoglobin concentrations equally high.

Treatments of the normal and $\beta$-thalassemics erythrocytes with DFO and DFP protected against the oxidation of GSH promoted by TBHP. According to Breuer et $a l .{ }^{18}$ DFP removes the iron from the cells, and then it is transferred to the DFO, allowing the regeneration of DFP. Better results were found when DFP was added followed by DFO, prior to the TBHP action. The protective action on GSH was the following: $\mathrm{DFO}<\mathrm{DFP}<\mathrm{DFP}+\mathrm{DFO}$ (ANOVA, $\mathrm{p}<0.05$ ). In the presence of the iron chelators, the GSH seemed to be partially protected from TBHP action. It can be inferred that the DFO or DFO + DFP could assist the organism of $\beta$ thalassemic patients to control the pathological mechanisms of oxidative stress, inherent to its condition.

Hemolysis induced by TBHP was much higher in $\beta$ thalassemic erythrocytes than in the normal ones. The samples treated with the iron chelators did not present protection against hemolysis.

It was observed $9 \%$ Heinz bodies in normal erythrocytes in the presence of TBHP, but its formation was prevented by DFO. However, the DFP did not inhibit the Heinz bodies' formation, a phenomenon consequent to the increase in the methemoglobin concentration. Although generally the individuals with $\beta$-thalassemia minor present only discrete anemia or no anemia, some alterations can be evidenced, such as the presence of Heinz bodies, as a result of an exacerbated oxidation. In this work, it was observed formation of about $5 \%$ of Heinz bodies in samples of $\beta$-thalassemia minor and $10 \%$ in samples of $\beta$-thalassemia major. Under the pro-oxidative oxidation by TBHP, they presented values of $34 \%$ and $43 \%$ of Heinz bodies, respectively, for $\beta$-thalassemia minor and major. In $\beta$-thalassemic major erythrocytes the elevated Heinz body percentages could not be prevented by $\mathrm{DFO}$ or DFO/DFP therapy.

The activity of G6-PD was lowered in the concentration of $5 \mathrm{mM} \mathrm{TBHP}$. At that TBHP concentration, samples treated with the DFO and DFP did not recover the level of G6-PD activity. The activities of G6-PD are higher in erythrocytes from $\beta$-thalassemic minor. Possible explanations for this fact could be related with metabolic alterations involved in protection on the redox states, such as the GSH levels, and/ or with elevated reticulocyte number, because of hemolysis.
In $\beta$-thalassemic major erythrocytes, on the other hand, the G6-PD activities were under normality and reduced by the TBHP effect.

Enzyme activities of GR in erythrocytes from $\beta$ thalassemic major were higher than the ones not carrying hemolytic illnesses, and did not change either after patients treatment with iron chelators or the addition of TBHP.

The activities of GR and G6-PD are normally higher in $\beta$-thalassemics in comparison to the normal individuals, due to necessity of the presence of these enzymes to regenerate the GSH. However, the rates are considered insufficient to regenerate the necessary amount of GSH required for the cells.

The G6-PD regenerates GSH through the generation of $\mathrm{NADPH}$, important for the maintenance of the integrity of certain protein in the mature erythrocytes. The low activities observed for this enzyme could be explained by the increased necessities of the $\beta$-thalassemic erythrocytes in keeping the cellular integrity, once that they present trends to the exacerbation of the oxidative processes. ${ }^{19}$

More research should be done, in order to better understand the oxidative metabolism of erythrocyte of $\beta$ thalassemic patients, especially involving the employment of iron chelators. New contributions are required to offer improvements, not only to guarantee better conditions of life to the $\beta$-thalassemic major but also to the $\beta$-thalassemic minor whose pathology tends to be minimized by presenting, in general, fewer and lighter signals and detectable symptoms.

\section{Conclusions}

$\beta$-thalassemia minor and major erythrocytes were more sensible to the pro-oxidative action of TBHP than the normal ones, presenting larger amount of Heinz bodies. Treatments of the normal and $\beta$-thalassemic erythrocytes with DFO and/ or DFP protected against the oxidation of GSH promoted by TBHP. In erythrocytes from normal individuals but not from $\beta$-thalassemics the DFO treatment showed a protective effect against methemoglobin formation promoted by TBHP.

\section{Resumo}

Uma das maiores consequências da sobrecarga do ferro na $\beta$-talassemia é a presença de ferro não ligado à transferrina (NTBI), um radical livre que age como um catalisador do radical livre do oxigenio, particularmente radical hidroxil (OH.). Estes radicais oxidam os lipideos e as proteinas da membrana causando danos irreversíveis às moléculas biologicamente importantes e às estruturas celulares. O tratamento com quelantes do ferro é importante para a melhoria da sobrevivência destes indivíduos. $O$ objetivo deste trabalho foi o estudo sobre o efeito da desferoxamina (DFO) e da deferiprona (DFP) em eritrócitos isolados de individuos normais e de pacientes com $\beta$-talassemias, sob a ação pró-oxidativa de TBHP. Neste trabalho foi estudada a 
ação in vitro da desferoxamina e o deferiprona no metabolismo oxidativo dos eritrócitos de pacientes $\beta$-talassêmicos atendidos no Centro de Hematologia e Hemoterapia do Paraná (Hemepar), Brasil, sob a ação pró-oxidativa de TBHP. Concentrações de metahemoglobina glutationa reduzida, índices de hemólises, atividades das enzimas G6PD e GR foram determinadas. Os indices de oxidação analisados foram maiores nos eritrócitos de individuos $\beta$-talassêmicos do que nos normais. Tratamentos dos eritrócitos normais e $\beta$-talassêmicos com DFO elou DFP protegem contra a oxidação de GSH promovida por TBHP. Rev. Bras. Hematol. Hemoter.

Palavras-chave: Quelantes de ferro; desferoxamina; deferiprona; eritrócitos.

\section{References}

1. Papanikolaou G, Pantopoulos K. Iron metabolism and toxicity. Toxicol Appl Pharmacol. 2005;202(2):199-211.

2. Gutteridge JM, Rowley DA, Halliwell B. Superoxide-dependent formation of hydroxyl radicals and lipid peroxidation in the presence of iron salts. Detection of 'catalytic' iron and anti-oxidant activity in extracellular fluids. Biochem J. 1982;206(3):605-9.

3. Lee R, Foerster J, Lukens J, Paraskevas F, Greer J. Rodgers G. Wintrobe's Clinical Hematology. 10th ed. Baltimore: Lippincott Williams \& Wilkins; 1999.

4. Fabron A, Tricta F. Terapia quelante oral com deferiprona em pacientes com sobrecarga de ferro. Revista Brasileira de Hematologia e Hemoterapia, 2003; 25:177-188.

5. Cohen AR, Galanell OR, Pennell DJ, Cunningham MJ, VIchinsky E. Thalassemia. Washington: American Society of Hematology; 2004.

6. Bernhardt PV. Coordination chemistry and biology of chelators for the treatment of iron overload disorders. Dalton Trans. 2007; (30):3214-20.

7. Chaves MA, Leonart MS, do Nascimento AJ. Oxidative process in erythrocytes of individuals with hemoglobin S. Hematology. 2008;13(3):187-92.

8. Halliwell B, Gutteridge JMC. Free Radicals in Biology and Medicine. 3rd Ed. New York: Oxford University Press; 1999.

9. Beutler E, Dern RJ, Alving AS. The hemolitic effect of primaquine. J Lab Clin Med. 1955;45:40-45.

10. Claro LM, Leonart MS, Comar SR, do Nascimento AJ. Effect of vitamins $\mathrm{C}$ and $\mathrm{E}$ on oxidative processes in human erythrocytes. Cell Biochem Funct. 2006;24(6):531-5.

11. Dacie J, Lewis SM. Practical Haematology. 8th ed. Edinburgh:Churchill Livingstone; 1995.

12. Evelyn KA, Malloy HAT. Microdetermination of oxyhemoglobin, methemoglobin and sulfhemoglobin in a single sample of blood. J Biol Chem. 1938;126:655-64.

13. Beutler E, Lichtman MA, Coller BS, Kipps TJK. Hematology. 5th ed. New York: Mc Graw-Hill; 1995

14. Beutler E, Duron O, Kelly BM. Improved method for the determination of blood glutathione. J Lab Clin Med. 1963; 61:882-8.

15. Pelissari CB, Stighen ST, Nascimento AJ. Leonart MSS. Padronização para a dosagem de hemoglobina extracelular pelo método da cianometahemoglobina. Revista Brasileira de Análises Clínicas, $1993 ; 25: 14-16$.

16. Van Kampra EJ, Zijistra WG. Standardization of hemoglobinometry, II. The hemoglobin cyanide method. Clinica Chimica Acta. 1961; 6:538-45.
17. Beutler E. Red Cell Metabolism: a manual of biochemical methods. 3rd ed. Orlando: Grune \& Stratton; 1984.

18. Breuer W, Ermers MJ, Pootrakul P, Abramov A, Hershko C, Cabantchik ZI. Desferrioxamine-chelatable iron, a component of serum non-transferrin-bound iron, used for assessing chelation therapy. Blood. 2001;97(3):792-8.

19. Chakraborty D, Bhattacharyya M. Antioxidant defense status of red blood cells of patients with beta-thalassemia and Ebetathalassemia. Clin Chim Acta. 2001;305(1-2):123-9.

Avaliação: Editor e dois revisores externos

Conflito de interesse: sem conflito de interesse

Recebido: 14/12/2008

Aceito após modificações: 30/04/2009 